\title{
Influence of Some Dairy Powders on the Qualitative Parameters of Bread
}

\section{Mustafa Kürşat DEMIR ${ }^{1 *}$, Nilgün ERTAŞ ${ }^{1}$, Durmuş SERT ${ }^{1}$}

\begin{abstract}
Bread, is one of the basic nutrients of Turkish people, is one of the first in providing energy, although it is rich in carbohydrate, and not sufficient in terms of protein, vitamins and minerals, it is suitable for enriching with natural additives. Dairy powder as skim milk powder, yogurt powder, buttermilk powder, colostrum powder, whey protein concentrate powder and lactose powder are obtained by spray drying of some dairy products. The target of this study is to enrich the bread samples with dairy powders and increase the usage of by-products in food systems. For this purpose, different dairy powder (skim milk powder (SMP), butter milk powder (BMP), yoghurt powder (YP), colostrum powder (CP), whey powder (WP) and lactose (L) were used in bread formulations (3\%). AACC Method 10.10 was used in bread making with some modifications. Bread volume, weight, specific volume, texture, porosity, symmetry, firmness (after 24 and 72 hours), crust and crumb color properties of the breads and rheological properties (extensograph) of dough samples were investigated. Bread weight, volume, specific volume, texture, firmness $(\mathrm{P}<0.01)$, symmetry and porosity $(\mathrm{P}<0.05)$ values were statistically effected by the powder types. While the highest bread volume value was determined with $\mathrm{CP}$, dairy powder addition gave lower bread volume values compared to control bread sample. Besides, $\mathrm{CP}$ addition gave desirable bread properties (darker crust color and softer crumb texture). According to rheological properties, the highest resistance to extension and energy values of dough samples was determined with YP addition, while CP addition gave the highest maximum extensibility values. As a consequence, dairy powder form could be used in bread formulations and further studies on dairy byproducts usage are recommended.
\end{abstract}

Keywords: Dairy by-products, Colostrum powder, Yoghurt powder, Butter milk powder, Whey powder, Lactose, Bread.

\footnotetext{
${ }^{1}$ Mustafa Kürşat DEMIR (Orcid ID:0000-0002-4706-4170), Nilgün ERTAŞ (Orcid ID: 0000-0002-0671-2485), Durmuş SERT (Orcid ID: 0000-0002-4073-0468), Necmettin Erbakan Üniversitesi Mühendislik ve Mimarlık Fakültesi Gıda Mühendisliği Bölümü, Meram, Konya, Türkiye

*Sorumlu Yazar/Corresponding Author: M. Kürşat DEMİR, e-mail: mkdemir@erbakan.edu.tr
}

Geliş tarihi / Received: 02-03-2020

Kabul tarihi / Accepted: 15-06-2020 


\section{INTRODUCTION}

Cereal products are the basic nutrient group of the society and they are important part of healthy nutrition since they contain significant nutrients (Demir and Elgün, 2014). Bread does not adequately meet the requirements for many macro or micronutrients (Skrbic and Filipcev, 2008; Demir and Elgün, 2014), therefore researchers explore the utilization of different ingredients and by-products in bread to improve the nutritional and functional properties of bread. In recent years, with the addition of dietary fiber and natural components that have antimicrobial and antioxidant properties, functional of products features are being developed in bakery products industry (Acun and Gül 2014; Gül and Şen, 2017).

Once upon a time, leavened breads that once did not contain any additives other than flour, water and salt, but nowadays, lots of food additives are used in the baking industry (Ribotta, 2001). In recent years, natural additives using is gaining popularity among the consumers as they are becoming more conscious about their diet and health (Asghar et al., 2011). Most bakery products can be easily enriched and supplemented with proteins, minerals and various vitamins at low cost (Indrani et al., 2007). Dairy ingredients and by-products are used in bakery products in various forms to improve their nutritional properties by increasing calcium and protein content and functional properties such as improvement of color, flavor and texture. Especially, lysine, methionine and tryptophan that are essential amino acids increase (Bilgin et al., 2006; Kenny et al., 2000). Dairy by-products affect texture, flavor and color of foods directly (Jacobson, 1997; Kinsella and Morr, 1984). Dairy powders are also good supplement in gluten-free bread formulations and addition of dairy powders resulted in improved volume, good appearance and sensory aspects of the loaves (Gallagher et al., 2003b, Nunes et al., 2009). Using dairy by-products in bakery products, browning reactions occurs giving the wide variety of potential flavours and stability as well as color. Browning is mainly a sugar-aminoacid interaction (Maillard-type reaction), forming brown polymers or melanoidins, during long-term (or very high temperatures) heating of a foodstuff, giving the cooked food its brown colouration (Huyghebaert, 1984; Gallagher et al., 2005). The dairy powders are perfect solution to those who lack immediate access to adequate refrigeration facilities. Dairy powders are produced by extracting water or fat from milk. The aim of converting milk into dairy powders is to convert the raw material to a product that can be stored without substantial loss of quality (Kalyankar et al., 2016).

In this study, the effects of addition colostrum powder (CP), butter milk powder (BMP), skim milk powder (SMP), yoghurt powder (YP), whey powder (WP), lactose (L) on rheological properties of dough and some external and internal properties of bread and possible usage of these products in bakery were investigated.

\section{MATERIALS AND METHODS}

\section{Materials}

Wheat flour, salt, baker's yeast, dairy ingredients and water were incorporated in to the formulation. The wheat flour was obtained from Hekimoğlu Un A.Ş., Konya, Turkey. Baker's yeast and refined salt were purchased from a local market, and the dairy ingredients such as CP (Colostrum powder), SMP (Skim milk powder), YP (Yoghurt powder), BMP (Butter milk powder), L (Lactose) and WP (Whey powder) were provided by a local dairy.

\section{Methods}

Bread ingredients were included 3.0\% yeast, 1.5.0 \% salt, $3.0 \%$ dairy powder ingredients (all based on $\%$ of flour weight). Amount of water to be added was calculated as farinograph water absorption. All the ingredients were kneading using a Hobart mixer for $5 \mathrm{~min}$. Shaping the kneaded 
dough for 30 minutes at $85 \%$ relative humidity and left to fermentation. Modified straight dough process (AACC 10-10B) was used (bulk fermentation: $30+30 \mathrm{~min}$, proofing: $60 \mathrm{~min}$ ) by bread making procedure (AACC, 1990). After that bread dough's were baked in an oven (Arçelik ARMD-580 oven, İstanbul, Turkey) for $25 \mathrm{~min}$ at $235 \pm 2{ }^{\circ} \mathrm{C}$.

The bread samples were standed and cooled at room temperature then stored in polyethylene bags until analysed. The quality properties of bread samples (loaf weight and volume) were measured immediately after 1 hour of fresh from the oven. Bread volume will be determined on the basis of displacement with rapeseed. Specific volume values $\left(\mathrm{cc} \mathrm{g}^{-1}\right)$ were calculated as dividing the volume by weight of bread samples (AACC, 1990). Lightness, redness and yellowness values of crust and crumb color of the bread samples were measured with chromameter (Konica Minolta Sensing, Inc., Osaka, Japan) as suggested by Francis (1998).

The crumb firmness of bread samples were measured with Test Instrument of Biological Materials at the $24^{\text {th }}$ and $72^{\text {nd }}$ hours after baking in Newton $\mathrm{cm}^{-2}$ by texture analyzer using the method of Aydin and Ögüt (1991). In this system sliced bread samples were placed on the movable bottom platform, and were compressed against the stationary platform. The process was carried out at a loading speed of 50 $\mathrm{mm} / \mathrm{min}$.

Sensory properties such as symmetry, porosity and texture were achieved after 24 hours. Sensorial characteristics (texture, symmetry and porosity) of bread samples were rated on a 1-10 scale, 5 being the most desirable. Effect of addition dairy products at $3 \%$ level on bread dough were measured by a Brabender extensograph (Brabender/ E model, Duisbug, Germany) using AACC 54-10 methods (AACC, 1990).

\section{Statistical Analysis}

Results of this study were performed with TARIST software program by one way analysis of variance. Statistically different means were compared using Duncan's multiple range tests, and a significant level of $\mathrm{P}<0.05$ was used.

\section{RESULTS AND DISCUSSION}

\section{Bread Properties}

Data for the effects of dairy powders on bread properties are presented in Table 1. Bread weight, volume, specific volume, texture, firmness $(\mathrm{P}<0.01)$, symmetry and porosity $(\mathrm{P}<0.05)$ values were statistically effected by the powder types.

Among the different dairy powder types, colostrum powder showed the lowest effect on bread weight. Breads with added SMP and BMP had significantly lower bread volumes than the other dairy powders. This similar effect has been reported before (Srivastava and Haridas Rao, 1993). Also, Sert el al. (2016) stated that BMP (56.3\%) and SMP (55.5\%) gave higher lactose content compared to other dairy powders and the lowest lactose content was also found in colostrum powder (16.1\%). High lactose content inhibits yeast activity. Therefore, low volume values might be due to the high lactose content of SMP and BMP. The highest bread volume was obtained with the colostrum powder addition. Colostrum powder has lower lactose content and higher fat and ash content than BMP, SMP and YP (Sert et al., 2016). Colostrum powder with high mineral content positively affected bread yeast activity compared to other powders. Elgün and Ertugay, (1995) stated that high fat content has shown shortening effect and high mineral content improved the bread yeast activity. Also, Gallagher et al. (2003a), ErdogduArnoczky et al. (1996), Gelinas et al. (1995) Kadhharmestan et al. (1998), Kenny et al. (2001) and Axford et al. (1968) reported that the dairy powders (i.e. skim milk powder, sodium caseinate) reduces the loaf volume because of the high protein content. Because, dough slackening and volume-depressing 
effects with dairy fractions have been reported frequently. Such fractions include whey proteins (powders or concentrates), casein, and lactose (Erdogdu- Arnoczky et al. 1996).

Table 1. Effects of dairy powders on bread properties ${ }^{1}$

\begin{tabular}{|c|c|c|c|c|c|c|c|c|}
\hline \multirow{2}{*}{ Samples } & \multirow{2}{*}{$\begin{array}{c}\text { Weight } \\
\text { (g) }\end{array}$} & \multirow{2}{*}{$\begin{array}{l}\text { Volume } \\
\text { (ml) }\end{array}$} & \multirow{2}{*}{$\begin{array}{l}\text { Specific } \\
\text { volume } \\
\left(\mathrm{ml} \mathrm{g}^{-1}\right)\end{array}$} & \multirow{2}{*}{$\begin{array}{c}\text { Texture } \\
(1-10)\end{array}$} & \multirow{2}{*}{$\begin{array}{c}\text { Symmetry } \\
(1-10)\end{array}$} & \multirow{2}{*}{$\begin{array}{c}\text { Porosity } \\
(1-10)\end{array}$} & \multicolumn{2}{|c|}{$\begin{array}{l}\text { Firmness } \\
\text { (Newton) }\end{array}$} \\
\hline & & & & & & & 1. day & 3. day \\
\hline SMP & $158.5^{\mathrm{a} * *}$ & $570.0^{\mathrm{cd}^{* *}}$ & $3.6^{\mathrm{c} * *}$ & $6.8^{b c * *}$ & $8.3^{\mathrm{a} *}$ & $7.0^{\mathrm{bc} *}$ & $30.9^{\mathrm{a}^{* *}}$ & $45.8^{b^{* *}}$ \\
\hline BMP & $154.5^{\mathrm{b} * *}$ & $552.5^{\mathrm{d}^{* *}}$ & $3.6^{\mathrm{c} * *}$ & $6.0^{\mathrm{c}^{* *}}$ & $8.0^{\mathrm{a}^{*}}$ & $7.5^{b^{*}}$ & $29.0^{\mathrm{a}^{* *}}$ & $49.1^{\mathrm{a}^{* *}}$ \\
\hline $\mathbf{Y P}$ & $149.2^{\mathrm{de} * *}$ & $637.5^{b^{* *}}$ & $4.3^{b^{* *}}$ & $7.5^{a b^{* *}}$ & $7.8^{a b^{*}}$ & $7.5^{b^{*}}$ & $24.3^{b^{* *}}$ & $43.5^{b^{* *}}$ \\
\hline $\mathbf{C P}$ & $148.3^{\mathrm{e}^{* *}}$ & $732.5^{\mathrm{a}^{* *}}$ & $5.0^{\mathrm{a}^{* *}}$ & $7.8^{a^{* *}}$ & $7.0^{\mathrm{c}^{*}}$ & $8.3^{\mathrm{a}^{*}}$ & $14.7^{\mathrm{c}^{* *}}$ & $31.1^{\mathrm{d}^{* *}}$ \\
\hline WP & $151.3^{\mathrm{cd}^{* *}}$ & $617.5^{b c * *}$ & $4.1^{b^{* *}}$ & $7.5^{a b^{* * *}}$ & $7.3^{b c^{*}}$ & $7.3^{b c *}$ & $27.8^{a b^{* *}}$ & $45.3^{\mathrm{b} * *}$ \\
\hline $\mathbf{L}$ & $152.4^{b c^{* *}}$ & $642.5^{b^{* *}}$ & $4.2^{b^{* *}}$ & $7.5^{a b^{* *}}$ & $6.8^{\mathrm{c}^{*}}$ & $6.8^{\mathrm{c}^{*}}$ & $24.6^{\mathrm{b}^{* * *}}$ & $39.3^{\mathrm{c}^{* *}}$ \\
\hline
\end{tabular}

1 The mean values with different superscript letters in a column are significantly different $(\mathrm{P}<0.01)$.

${ }^{2}$ SMP: Skim milk powder, BMP: Butter milk powder, YP: Yoghurt powder, CP: Colostrum powder, WP: Whey powder, L: Lactose

${ }^{*} \mathrm{P}<0.05,{ }^{* *} \mathrm{P}<0.01, \mathrm{~ns}=$ not significant

The specific loaf volume was $5.0 \mathrm{ml} \mathrm{g}^{-1}$ for $\mathrm{CP}$ bread. CP addition in bread making gave the highest specific loaf volume. That whey proteins cause the greatest increase in the specific volume of breads has been reported by Nunes et al. (2009). Plessas et al. (2005), reported that the kefir breads had lower specific volumes. In addition, the highest texture values were obtained with addition of CP in breads. Symmetry values ranged 6.8 to 8.3 for bread with addition different dairy powders. Skim milk powder was found to cause an increase in the symmetry of breads. Figure 1 shows the porosity of breads with addition of dairy powders. The important physicochemical parameter, as indicator of bread quality is the porosity of the crumb. The porosity increased in the case of CP addition. The addition of CP resulted a decrease in the bread firmness, the increase in bread firmness with addition CP might be due to reduction in bread volume. There was a negative correlation between loaf volume and crumb hardness (Singh et al., 2003; Gallagher et al., 2003b). Gallagher et al. (2003b) reported that crust hardness was not affected by the addition of dairy powder and remained softer than the control samples.
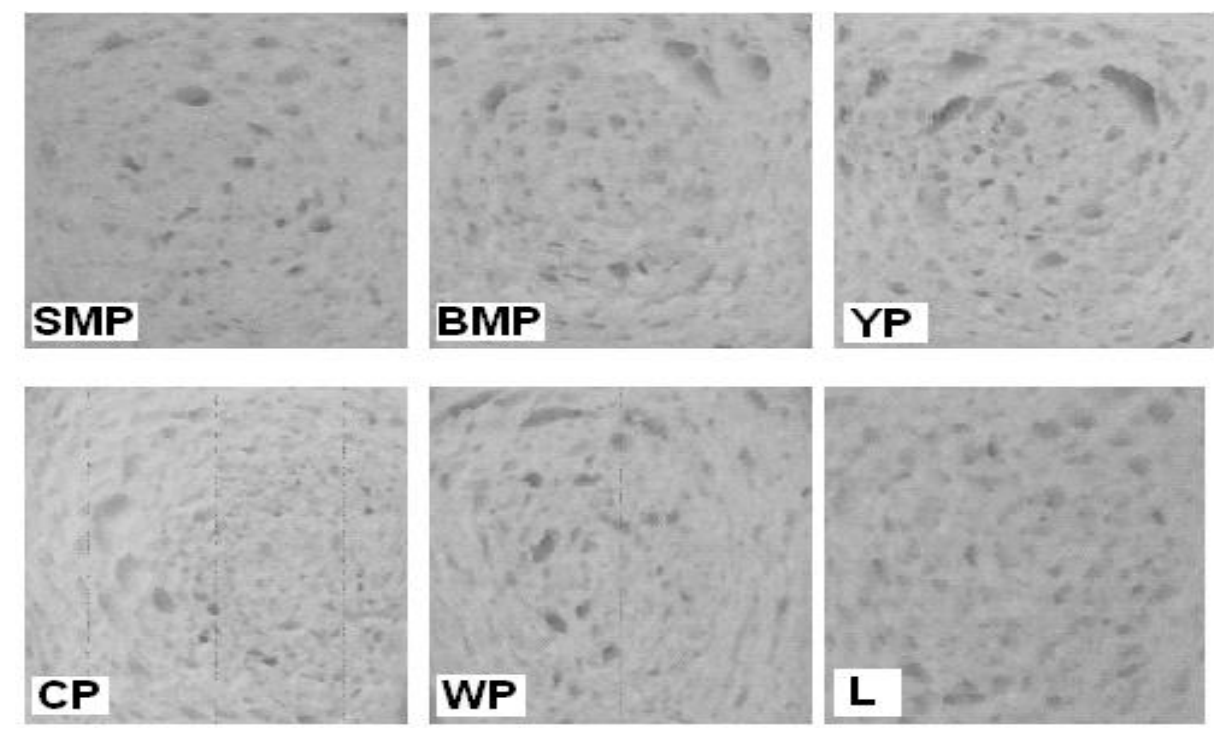

Figure 1 Sample images (photo/8 megapixel) of breads. SMP: Skim milk powder, BMP: Butter milk powder, YP: Yoghurt powder, CP: Colostrum powder, WP: Whey powder, L: Lactose 


\section{Crust and Crumb Color}

Table 2 provides information on the crust and crumb color of the breads. The $\mathrm{L}^{*}$ scale gives and ranges from 0 black to 100 white; darkness to lightness. The $\mathrm{L}^{*}$ values of crust color ranged from 52.84 to 68.28. The SMP breads showed the highest crust $\mathrm{L}^{*}$ values and $\mathrm{CP}$ breads had the lowest. $\mathrm{CP}$ addition gave the darker crust color. Gallagher et al. (2003b) reported that dairy powders gave the darker bread color. These darker colors may be due to the Maillard browning and caramelisation. $\mathrm{a}^{*}$ values of crust color ranged from 3.22 to 13.72. YP resulted in a redder color for the crust. The lowest $\mathrm{a}^{*}$ values was observed fort the crust of the SMP bread. The $b^{*}$ values of crust was highest for CP bread compared to that of the lowest $b^{*}$ values were observed for the crust of the L and SMP breads. The crumb color of bread with addition different dairy powder ranged from 67.90 to 74.75 .

Among the different dairy powders, YP resulted in a lighter and SMP resulted in a darker color for the crumb. These results agreed with the previous study of Gallagher et al. (2003b). The addition of $\mathrm{CP}$ decreased the $\mathrm{b}^{*}$ values of crumb by descriptively.

\section{Extensograph Properties}

The effect of dairy powders on the extensograph properties are shown in Table 3. Resistance to extension values of dough samples enriched with dairy powders at 135 min were varied between 626 and $806 \mathrm{BU}$, and the highest resistance to extension value was determined with yoghurt powder. The use of colostrum powder increased the extensibility value $(147 \mathrm{~mm})$ more than other dairy powders. Also colostrum powder gave the highest bread volume. Şahin et al., (2013) stated that among the extensograph features, only the correlation between extensograph elasticity and bread volume was found significant. The lowest ratio of resistance to extension to extensibility value was obtained with colostrum powder that indicating the high extensibility of the dough.

Table 2. Effect of dairy powders on crumb and crust color of bread samples ${ }^{1}$

\begin{tabular}{|c|c|c|c|c|c|c|}
\hline \multirow[t]{2}{*}{ Samples $^{2}$} & \multicolumn{3}{|c|}{ Crust } & \multicolumn{3}{|c|}{ Crumb } \\
\hline & $L^{*}$ & $a^{*}$ & $b^{*}$ & $L^{*}$ & $a^{*}$ & $b^{*}$ \\
\hline SMP & $68.28^{a * *}$ & $3.22^{\mathrm{d}^{* *}}$ & $29.37 \mathrm{bc} * *$ & $67.90^{\mathrm{d}^{* *}}$ & $-2.57^{\mathrm{ns}}$ & $18.59^{\mathrm{ns}}$ \\
\hline BMP & $63.99^{\mathrm{b} * *}$ & $9.47^{\mathrm{c}^{* *}}$ & $30.91^{\mathrm{b} * *}$ & $71.62^{b c^{* *}}$ & $-2.65^{\mathrm{ns}}$ & $18.46^{\mathrm{ns}}$ \\
\hline $\mathbf{Y P}$ & $52.84^{\mathrm{d}^{* *}}$ & $13.72^{\mathrm{a}^{* *}}$ & $28.50^{\mathrm{c} * *}$ & $74.75^{\mathrm{a}^{* *}}$ & $-2.67^{\mathrm{ns}}$ & $18.22^{\mathrm{ns}}$ \\
\hline $\mathbf{C P}$ & $58.59^{\mathrm{c}^{* *}}$ & $11.64^{b^{* *}}$ & $33.78^{\mathrm{a}^{* *}}$ & $74.49^{a b^{* *}}$ & $-2.59^{\mathrm{ns}}$ & $17.35^{\mathrm{ns}}$ \\
\hline WP & $57.02^{\mathrm{c}^{* *}}$ & $12.92^{a b^{* *}}$ & $30.88^{b^{* *}}$ & $70.99^{\mathrm{c}^{* *}}$ & $-2.46^{\mathrm{ns}}$ & $18.36^{\mathrm{ns}}$ \\
\hline $\mathbf{L}$ & $57.27^{\mathrm{c}^{* *}}$ & $12.32^{a^{* * *}}$ & $29.58^{\text {bc** }}$ & $71.88^{a b c * *}$ & $-2.51^{\mathrm{ns}}$ & $17.68^{\mathrm{ns}}$ \\
\hline
\end{tabular}

\footnotetext{
1 The mean values with different superscript letters in a column are significantly different $(\mathrm{P}<0.01)$.

${ }^{2}$ SMP: Skim milk powder, BMP: Butter milk powder, YP: Yoghurt powder, CP: Colostrum powder, WP: Whey powder, L: Lactose

${ }^{*} \mathrm{P}<0.05,{ }^{* *} \mathrm{P}<0.01, \mathrm{~ns}=$ not significant
}

Fig 2 shows the effects of dairy ingredients in bread dough on resistance to extension measured with the extensograph. Concerning Rmax, YP addition promoted the highest increase (976 BU). This is agreement with data given by Bilgin et al. (2006). Baking performance takes important role to predict resistance to extension and extensibility (Anderssen et al., 2004). As a good determinant of flour strength and bread properties, energy value, significantly affected by the addition dairy powders.

Fig 3 shows the effects of dairy ingredients on energy values which measured with the extensograph. YP addition gave the highest energy values. As observed by Bilgin et al. (2006), BMP addition gave the highest energy values. The increase in Rmax and energy values due to the better disulfide linkages of dairy products. There was an increase in dough extensibility with the addition of 
$\mathrm{CP}$ and the lowest extensibility value was obtained from the dough in which WP was added. Zadow (1981) have found that addition of WPC (whey protein concentrate) in bread formulation caused weaker and less elastic dough.

Table 3. Effects of dairy powders on extensograph measurements ${ }^{1}$

\begin{tabular}{|c|c|c|c|c|c|c|c|c|c|}
\hline \multirow{2}{*}{$\begin{array}{l}\text { Doughs }^{2} \\
\text { Min }^{3} . \\
\end{array}$} & \multicolumn{3}{|c|}{$\mathbf{R}(\mathbf{B U})$} & \multicolumn{3}{|c|}{ Extensibility (Ext.) (mm) } & \multicolumn{3}{|c|}{ R Ext." } \\
\hline & 45 & 90 & 135 & 45 & 90 & 135 & 45 & 90 & 135 \\
\hline SMP & $479^{b^{* * * *}}$ & $658^{b^{* * * *}}$ & $703^{\mathrm{c}^{* * * *}}$ & $144^{b^{* * *}}$ & $128^{\mathrm{c}^{* * *}}$ & $123^{b^{* * * *}}$ & $3.4^{\mathrm{a}^{* * * *}}$ & $5.2^{a b^{* * * *}}$ & $5.8^{\mathrm{bc} * * *}$ \\
\hline BMP & $423^{\mathrm{c}^{* * * *}}$ & $652^{b^{* * * *}}$ & $700^{c^{* * * *}}$ & $151^{\mathrm{b} * *}$ & $138^{a b^{* *}}$ & $125^{b^{* * * *}}$ & $2.9^{b^{* * * *}}$ & $4.7^{b^{* * * *}}$ & $5.6^{\mathrm{c}^{* * * *}}$ \\
\hline YP & $510^{\mathrm{a}^{* * * *}}$ & $714^{\mathrm{a}^{* * * *}}$ & $806^{\mathrm{a}^{* * * *}}$ & $141^{\mathrm{b} * *}$ & $129^{c^{* * *}}$ & $126^{\mathrm{b}^{* * * *}}$ & $3.6^{\mathrm{a}^{* * * *}}$ & $5.6^{\mathrm{a}^{* * * *}}$ & $6.4^{\mathrm{a}^{* * * *}}$ \\
\hline $\mathbf{C P}$ & $406^{\mathrm{d}^{* * *}}$ & $542^{\mathrm{d}^{* * * *}}$ & $626^{\mathrm{d}^{* * * *}}$ & $162^{a^{* * *}}$ & $142^{\mathrm{a}^{* * *}}$ & $147^{a^{* * * *}}$ & $2.5^{b^{* * * *}}$ & $3.8^{\mathrm{c}^{* * * *}}$ & $4.3^{\mathrm{d}^{* * * *}}$ \\
\hline WP & $398^{\mathrm{d}^{* * *}}$ & $627^{\mathrm{c}^{* * * *}}$ & $746^{\mathrm{b}^{* * * *}}$ & $143^{b^{* * *}}$ & $131^{\mathrm{bc} * *}$ & $117^{\mathrm{b}^{* * * *}}$ & $2.8^{\mathrm{b}^{* * * *}}$ & $4.8^{\mathrm{b}^{* * * *}}$ & $6.4^{\mathrm{a}^{* * * *}}$ \\
\hline $\mathbf{L}$ & $399^{d^{* * *}}$ & $643^{b c * * *}$ & $721^{\mathrm{c}^{* * * *}}$ & $144^{b * *}$ & $132^{\mathrm{bc} * *}$ & $118^{b^{* * *}}$ & $2.8^{b^{* * * *}}$ & $4.9^{b^{* * * *}}$ & $6.2^{a b^{* * *}}$ \\
\hline
\end{tabular}

${ }^{1}$ The mean values with different superscript letters in a column are significantly different $(\mathrm{P}<0.01)$.

${ }^{2}$ SMP: Skim milk powder, BMP: Butter milk powder, YP: Yoghurt powder, CP: Colostrum powder, WP: Whey powder, L: Lactose

${ }^{3}$ Min: Minute

${ }^{*} \mathrm{P}<0.05,{ }^{* *} \mathrm{P}<0.01,{ }^{* * *} \mathrm{P}<0.001, \mathrm{~ns}=$ not significant

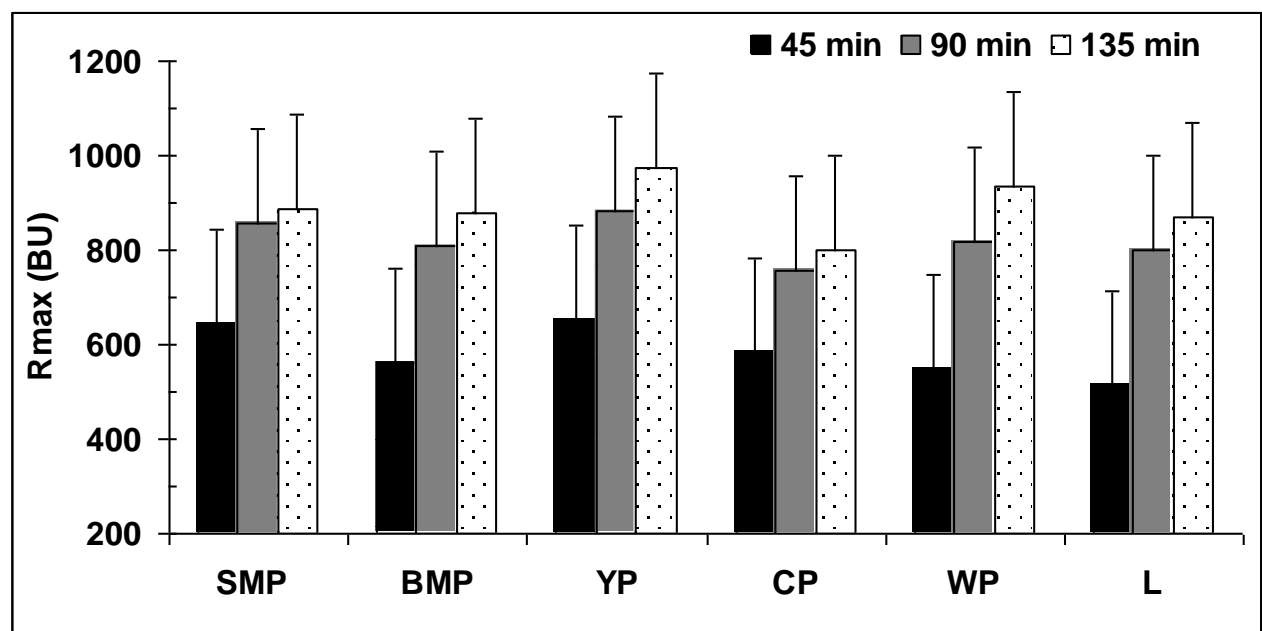

Figure 2. Effects of dairy ingredients on resistance to extension measured with the extensograph. SMP: Skim milk powder, BMP: Butter milk powder, YP: Yoghurt powder, CP: Colostrum powder, WP: Whey powder, L: Lactose

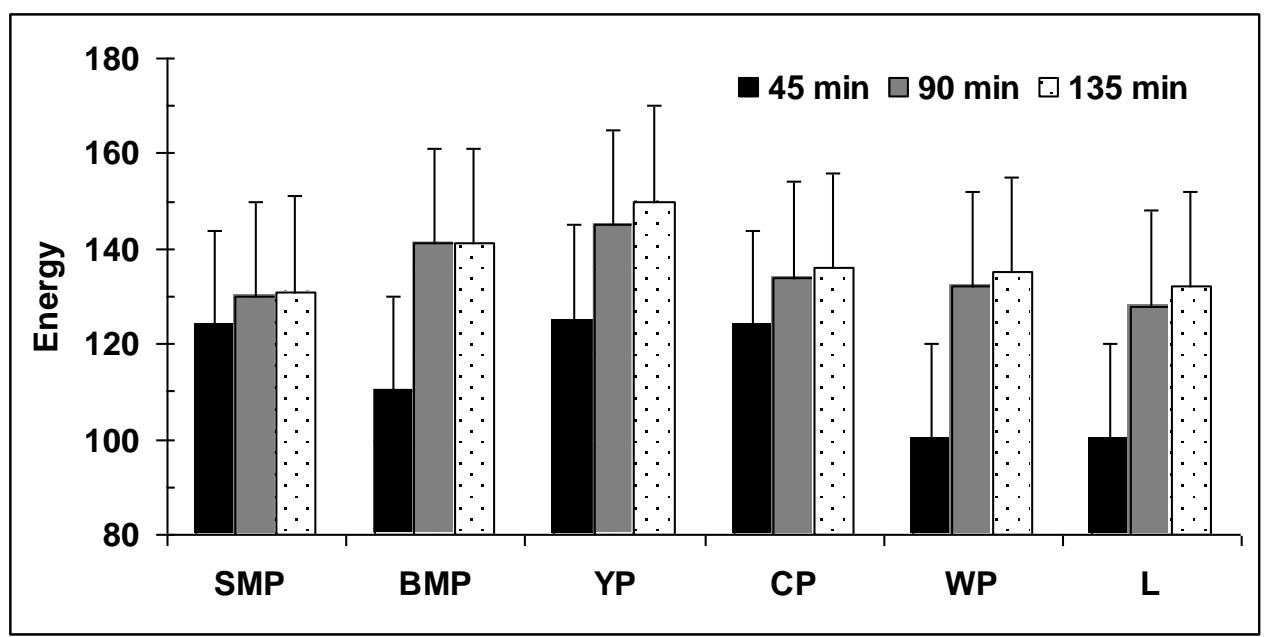

Figure 3. Effects of dairy ingredients on bread dough energy $\left(\mathrm{cm}^{2}\right)$ measured with the extensograph. SMP: Skim milk powder, BMP: Butter milk powder, YP: Yoghurt powder, CP: Colostrum powder, WP: Whey powder, L: Lactose 


\section{CONCLUSION}

Overall, it was found that the addition of colostrum powder improves the lowest bread weight, bread volume and specific volume, and good texture and porosity. The addition of skim milk powder resulted in increased bread symmetry. 1. and 3. day firmness of bread samples were significantly decreased, while colostrum was added in bread formulation. The study of rheological properties of bread dough showed that yoghurt powder gave the highest resistance to extension and energy values. The maximum extensibility values were obtained with colostrum powder. As a result of this study, colostrum powder could be good additive for bread formulations to improve bread quality paramaters due to its functional properties.

\section{REFERENCES}

AACC, 1990. American Association of Cereal Chemists, Approved methods of the AACC: 8th ed., The association:St. Poul, MN.

Acun S, Gül H, 2014. Effects of grape pomace and grape seed flours on cookie quality. Quality Assurance and Safety of Crops and Foods, 6(1): 81-88.

Anderssen RS, Bekes F, Gras WP, Nikolow A, Wood TJ, 2004. Wheat-flour dough extensibility as a discriminator for wheat varietes. Journal of Cereal Science, 39(2): 195-203.

Asghar A, Anjum FM, Allen JC, 2011. Utilization of dairy byproduct proteins, surfactants, and enzymes in frozen dough. Critical Reviews in Food Science and Nutrition, 51(4): 374-382.

Axford DWE, Colwell KH, Confor SJ, Elton GAH, 1968. Effect of loaf specific volume on the rate and extent of staling in bread. Journal of the Science of Food and Agriculture, 19(2): 95-101.

Aydın C, Öğüt H, 1991. Determination of some biological properties of Amasya apple and hazelnuts. Selcuk University Agriculture Faculty Journal, 1: 45- 54.

Bilgin B, Dağlıŏlu O, Konyalı M, 2006. Functionality of bread made with pasteurized whey and/or buttermilk. Italian Journal of Food Science, 18(3): 277-286.

Demir MK, Elgün A, 2014. Comparison of autoclave, microwave, IR and UV-C stabilization of whole wheat flour branny fractions upon the nutritional properties of whole wheat bread. Journal of Food Science and Technology, 51(1): 59-66.

Elgün A, Ertugay Z, 1995. Tahıl İşleme Teknolojisi. Atatürk Üniversitesi Ziraat Fakültesi Yayınları, no:718), Erzurum. Türkiye.

Erdogdu-Arnoczky N, Czuchajowska Z, Pomeranz Y, 1996. Functionality of whey and casein in fermentation and in breadbaking by fixed and optimized procedures. Cereal Chemistry, 73(3): 309-316.

Francis FJ, 1998. Colour Analysis, ed: Nielsen S.S.,An Aspen Publishers: Maryland, Gaithersnurg, USA., p:599612.

Gallagher E, Gormley TR, Arendt EK, 2003a. Crust and crumb characteristics of gluten free breads. Journal of Food Engineering 56 (2-3): 153-161.

Gallagher E, Kenny S, Arendt EK, 2005. Impact of dairy protein powders on biscuit quality. European Food Research and Technology, 221(3-4): 237-243.

Gallagher E, Kunkel A, Gormley TR, Arendt EK, 2003b. The effect of dairy and rice powder addition on loaf and crumb characteristics, and on shelf life (intermediate and long-term) of gluten-free breads stored in a modified atmoshere. European Food Research and Technology, 218(1): 44-48.

Gelinas P, Audet J, Lachsnce O, Vachon M, 1995. Fermented dairy ingredients for bread: effects on dough rheology and bread characteristics. Cereal Chemistry, 72(2): 151-154.

Gül H, Şen H, 2017. Effects of pomegranate seed flour on dough rheology and bread quality. CyTA-Journal of Food, 15(4): 622-628.

Huyghebaert A, 1984. Applications in confectionery and bakery products: Milk Protein. In Proceedings of the International Congress on milk proteins, Luxemburg, 1984, pp. 217-223. 
Indrani D, Prabhasankar P, Rajiv J, Venkateswara Rao GV, 2007. Influence of whey protein concentrate on rheological characteristics of dough, microstructure and quality of unleavened flat bread (parotta). Food Research International 40 (10): 1254-1260.

Jacobson KA, 1997. Whey protein concentrates as functional ingredients in baked goods. Cereal Foods World, 42(3): 138-141.

Kadharmestan C, Baik BK, Czuchajowska Z, 1998. Whey protein concentrate treated with heat or high hydrostatic pressure in wheat-based products. Cereal Chemistry, 75(5): 762-766.

Kalyankar SD, Deshmukh MA, Chopde SS, Khedkar CD, Lule VK, Deosarkar SS, 2016. Milk Powder. In: Caballero B, Finglas P, Toldrá F. (eds.) The Encyclopedia of Food and Health, Oxford Academic Press, pp. 724- 728.

Kenny S, Wehrle K, Stanton C, Arendt EK, 2000. Incorporation of dairy ingredients into wheat bread: effects on dough rheology and bread quality. European Food Research and Technology, 210(6), 391-396.

Kenny S, Wehrle K, Auty M, Arendt EK, 2001. Influence of sodium caseinate and whey protein on baking properties and rheology of frozen dough. Cereal Chemistry, 78(4): 458-463.

Kinsella JE, Morr CV, 1984. Milk proteins: physicochemical and functional properties. Critical Reviews in Food Science and Nutrition, 21(3): 197-262.

Nunes MHB, Ryan LAM, Arendt EK, 2009. Effect of low lactose dairy powder addition on the properties of gluten-free batters and bread quality. European Food Research and Technology, 229(1), 31-41.

Plessas S, Pherson L, Bekatorou A, Nigam P, Koutinas AA, 2005. Bread making using kefir grains as baker's yeast. Food Chemistry, 93(4): 585-589.

Ribotta PD, León AE, Añón MC, 2001. Effect of freezing and frozen storage of doughs on bread quality. Journal of Agricultural and Food Chemistry, 49(2): 913-918.

Sert D, Demir MK, Ertaş N, 2016. Rheological, physical and sensorial evaluation of cookies supplemented with dairy powders. Food Science and Technology International, 22(3): 196-202.

Singh N, Bajaj IK, Singh RP, Gujral HS, 2003. Effect of different additives on mixograph and bread making properties of Indian wheat flour. Journal of Food Engineering 56(1): 89-95.

Škrbić B, Filipčev B, 2008. Nutritional and sensory evaluation of wheat breads supplemented with oleic-rich sunflower seed. Food Chemistry, 108(1): 119-129.

Srivastava AK, Haridas Rao P, 1993. Effect of using different sources of milk products on the quality of bread. Journal of Food Science and Technology, 30(2): 109-113.

Şahin M, Göçmen Akçacık A, Aydoğan S, Demir B, Önmez H, Taner S, 2013. Ekmeklik buğday ununda ekmek hacmi ile bazı fizikokimyasal ve reolojik özellikler arasındaki ilişkilerin tespiti. Tarla Bitkileri Merkez Araştırma Enstitüsü Dergisi, 22(1): 13-19

Zadow JG, 1981. Measurement of the effect of whey protein concentrates on fermenting doughs by the Instron Tester. Australian Journal of Dairy Technology, 36(2), 56-59. 